\title{
LC-MS Analysis of Phenolic Acids, Flavonoids and Betanin from Spineless Opuntia ficus-indica Fruits
}

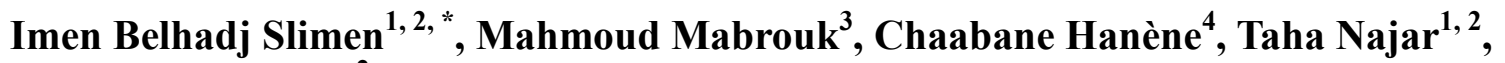 \\ Manef Abderrabba ${ }^{2}$ \\ ${ }^{1}$ Department of Animal, Food and Halieutic Resources, National Agronomic Institute of Tunisia, Mahragen City, Tunisia \\ ${ }^{2}$ Laboratory of Materials, Molecules and Applications, Preparatory Institute for Scientific and Technical Studies, La Marsa, Tunisia \\ ${ }^{3}$ Central Laboratory, Institute of Arid Regions, Medenine, Tunisia \\ ${ }^{4}$ Laboratory of Bioagressors and Integrated Protection in Agriculture, National Institute of Agronomy of Tunisia, Mahragen City, Tunisia
}

Email address:

belhadj_slimen_imen@yahoo.fr(I. B. Slimen)

${ }^{*}$ Corresponding author

\section{To cite this article:}

Imen Belhadj Slimen, Mahmoud Mabrouk, Chaabane Hanène, Taha Najar, Manef Abderrabba. LC-MS Analysis of Phenolic Acids, Flavonoids and Betanin from Spineless Opuntia ficus-indica Fruits. Cell Biology. Vol. 5, No. 2, 2017, pp. 17-28.

doi: $10.11648 /$ j.cb.20170502.12

Received: February 16, 2017; Accepted: March 11, 2017; Published: April 1, 2017

\begin{abstract}
Opuntia ficus-indica belongs to the Cactaceae family and is widespread in semi-arid and arid regions. Cactus pears are known for their health promoting properties which are due to a variety of bioactive molecules. This study aims to identify and quantify phenolic acids, flavonoids and betanin from spineless Opuntia ficus-indica fruits. Fresh mature samples were crushed, and extracted with 50\% aqueous ethanol. The identification process was carried out using a Shimadzu high performance liquid chromagraph equipped with a quadrupole mass spectrum. Quantification was made using calibration curves of analytical standards. 9 phenolic acids, 1 flavan-3-ol, 2 flavanones, 3 flavonols, 6 flavones and 2 betacyanins were identified. Important levels of betanin, quinic acid, cirsiliol, acacetin, transcinnamic acid, rutin and naringin were calculated. Our results indicated that Opuntia ficus-indica fruits are an important dietary source of phenolic compounds and betalains with high antioxidant capacity.
\end{abstract}

Keywords: Opuntia ficus-indica, Cactus Pear, Polyphenols, Betanin

\section{Introduction}

Cacti are distinctive and unusual plants especially adapted to extremely arid and hot climates in addition to nonirrigated lands thanks to their $\mathrm{CO}_{2}$ fixation capacity (Crassulacean Acid Metabolism). Their stems expand into green succulent structures containing the chlorophyll, while the leaves are the spines for which cacti are well known. Opuntia ficus-indica is the most important cactus species in agriculture today. It is widely used as food, fodder, dye, source of energy and has role in ecosystem remediation [1].

Opuntia fruits are fleshy and elongated berries, varying in shape, size and color (orange, yellow, red, purple, green, white) and have aconsistent number of hard seeds [2]. Their weight varies from $80 \mathrm{~g}$ to $140 \mathrm{~g}$, and the average of edible portion is about $54.18 \%$ [3]. Cactus pear is a food of neutraceutical and functional importance. The effect of prickly pear extracts on burned wound, oedema and indigestion was shown to be better than that of stem extracts [4]. Consumption of prickly pears enhances the body redox balance and decreases lipid peroxidation. At comparable levels to those of cactus pear, vitamin $\mathrm{C}$ supplementation does not significantly attenuate oxidative stress in humans [5, 6]. Siriwrdhana et al. [7] reported an opposite relation between increasing doses of cactus fruit extracts and oxidative-induced DNA damage. Cactus fruits due their functional interest to their content of bioactive molecules. Numerous phytochemicals were identified: phenolic acids, flavonoids, betalains, ascorbic acid, carotenoids and tocopherols. Indeed, prickly pears contain considerable amounts of vitamins, amino acids, sterols, fatty acids, sugars and minerals $[8,9]$. This paper aims to identify and quantify 
phenolic acids, flavonoids and betalains from Tunisian spineless Opuntia ficus-indica fruits.

\section{Experimental}

\subsection{Plant Material}

Spineless Opuntia ficus-indica fruits were harvested at physiological maturity from the improved pasture managed by the Office of Livestock and Pasture, and located in Sawwaf, Zaghouan governorate (northern Tunisia). Sawwaf has a semi-arid climate, according to the Emberger climate classification. The average annual temperature is $17.8^{\circ} \mathrm{C}$ and the average annual rainfall is $447 \mathrm{~mm}$. Collected fruits were immediately brought to laboratory and stored at $-20^{\circ} \mathrm{C}$ until use.

\subsection{Extract Preparation}

The peel was manually removed then fruits were washed, chopped into small pieces, homogenized with aqueous ethanol $(1: 2 ; \mathrm{w}: \mathrm{v})$, diluted with distilled water $(1: 2 \mathrm{v}: \mathrm{v})$ and subjected to a solid-liquid extraction at $4^{\circ} \mathrm{C}$ for $18 \mathrm{~h}$. Homogenates were then centrifuged at $4500 \mathrm{~g}$ at $4^{\circ} \mathrm{C}$ for $15 \mathrm{~min}$. The supernatants were collected and stored at $-20^{\circ} \mathrm{C}$ until analysis.

\subsection{Apparatus and LC-MS Conditions}

Chromatography was performed on Shimadzu Ultra Fast Liquid system (Shimadzu prominence UFLC $x$, Japon). HPLC separations were performed on an AQUASIL thermo $\mathrm{C} 18(3 \times 150 \mathrm{~mm}, 3 \mu \mathrm{m})$ at $40^{\circ} \mathrm{C}$. An AQUASIL thermoC18 $(3 \times 10 \mathrm{~mm}, 3 \mu \mathrm{m})$ guard column was used. Chromatographic separation conditions for phenolic acids and flavonoids were as follow: The mobile phase consisted of water $+0.1 \%$ formic acid (A) and methanol $+0.1 \%$ formic acid (B). The separation lasted $55 \mathrm{~min}$, followed by $5 \mathrm{~min}$ equilibrium time. The binary gradient elution was as follows: $0-45 \mathrm{~min}$, $10 \% \mathrm{~B}$; 45-55 min, $100 \% \mathrm{~B}$; 55-55.1 min, 10\% B; 55.1-60 min, $10 \% \mathrm{~B}$. The flow rate was $0.4 \mathrm{~mL} / \mathrm{min}$, and the injection volume was $5 \mu \mathrm{L}$ for analysis. Betanin separation lasted 25 min, with an additional 5 min equilibrium time. The mobile phase consisted of water $+2 \%$ formic acid (A) and methanol (B). The binary gradient elution was planned as follows:

(a)

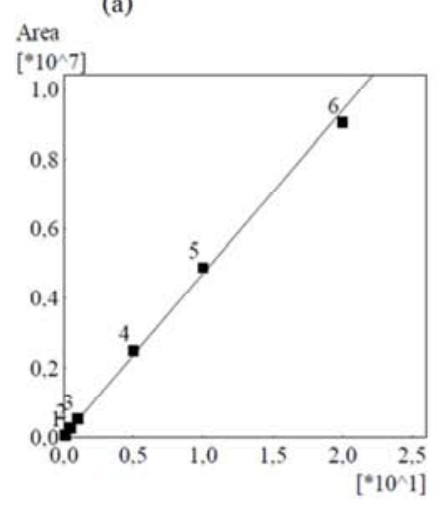

(b)

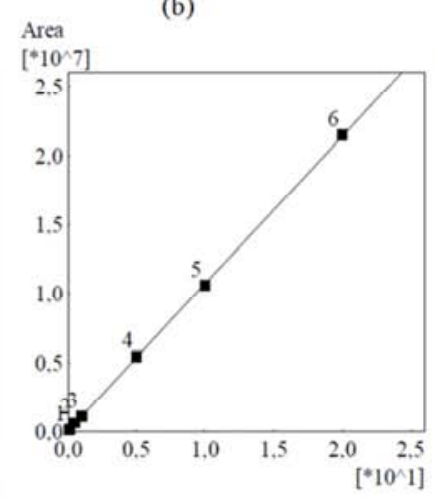

0.01-15 $\min , 5 \%(\mathrm{~B}) ; 15-20 \mathrm{~min}, 15 \%(\mathrm{~B}) ; 20-22 \mathrm{~min}, 70 \%$ (B); $22-25 \mathrm{~min}, 100 \%$ (B); 25-25.01 min, $100 \%$ (B); 25.01$30 \mathrm{~min}, 5 \% \mathrm{~B}$. Quantitative determination was carried out using calibration curves of standards.

A Shimadzu 2020 (Japon) Quadrupole mass spectrometer equipped with a positive/negative ESI source was used as a detector. Mass spectrometer was operated in the negative selected ion monitoring (SIM) with capillary voltage at $1.2 \mathrm{~V}$ for phenolic compounds identification, and in a positive SIM for betanin. The conditions of MS analysis were designed as follow: the spray voltage was $-3.5 \mathrm{~V}$, the desolving line temperature was $250^{\circ} \mathrm{C}$, the nebulizer gas flow was 1.5 $\mathrm{L} / \mathrm{min}$, the heat block was set at $400^{\circ} \mathrm{C}$, the drying gas flow was 12.00 and 15.00 respectively for phenolics and betanin. Finally the detector voltage was $1.2 \mathrm{~V}$.

\subsection{Antioxidant Activity}

Antiradical activity was measured with DPPH. (1,1diphenyl-2-picrylhydrazyl radical) as described by BrandWilliams et al. [10] and modified by Thaipong et al. [11]. The stock solution was prepared by dissolving $24 \mathrm{mg}$ DPPH with $100 \mathrm{~mL}$ methanol and stored at $-20^{\circ} \mathrm{C}$ until use. The working solution was obtained by mixing $10 \mathrm{~mL}$ of the stock solution with $45 \mathrm{ml}$ of methanol to obtain an absorbance of $1.1 \pm 0.02$ units at $515 \mathrm{~nm}$. To evaluate the antiradical activity, $150 \mu \mathrm{L}$ of each extract was allowed to react with $2850 \mu \mathrm{L}$ of the DPPH solution for $24 \mathrm{~h}$ in the dark. The absorbance was taken at $515 \mathrm{~nm}$. Trolox (6-hydroxy-2,5,7,8tetramethylchroman-2-carboxilic acid) was used as a standard. The calibration curve was linear between 25 and $800 \mu \mathrm{M}$ Trolox. Results are expressed as $\mathrm{mg} \mathrm{TE} / \mathrm{g}$ of sample fresh weight.

\section{Results and Discussion}

\subsection{Method Linearity}

The linear range of the standard solutions was studied. Calibration curves were linear across a range of concentrations varying from $0.1-20 \mathrm{mg} / \mathrm{L}$. All regression coefficients were higher than 0.99 . Calibration curves of quinic acid, catechin $(+)$, hyperoside and rutin are presented in Figure 1.
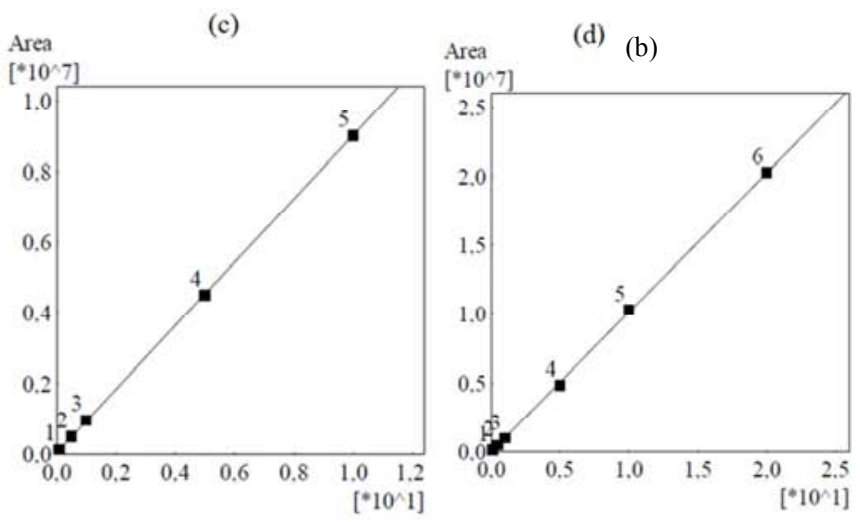

Figure 1. Calibration curves of (a) Quinic acid, (b) Catechin (+) (c) Hyperoside (d) Rutin. 


\subsection{Identification}

High performance liquid chromatography with gradient elution is a widely used technique for the separation and the quantification of phenolic compounds. The ESI source at negative ion mode was selected for the analysis of phenolic compoundswhile the positive mode was selected for betanin.
Figure 2 shows the total ion chromatogram (TIC) of phenolic compounds from spineless Opuntia fruit extract. A total of 21 phenolic molecules in addition to a betanin molecule were identified and confirmed by comparing their MS features and retention times with those of reference compounds. Phenolic compounds include phenolic acids and flavonoids.

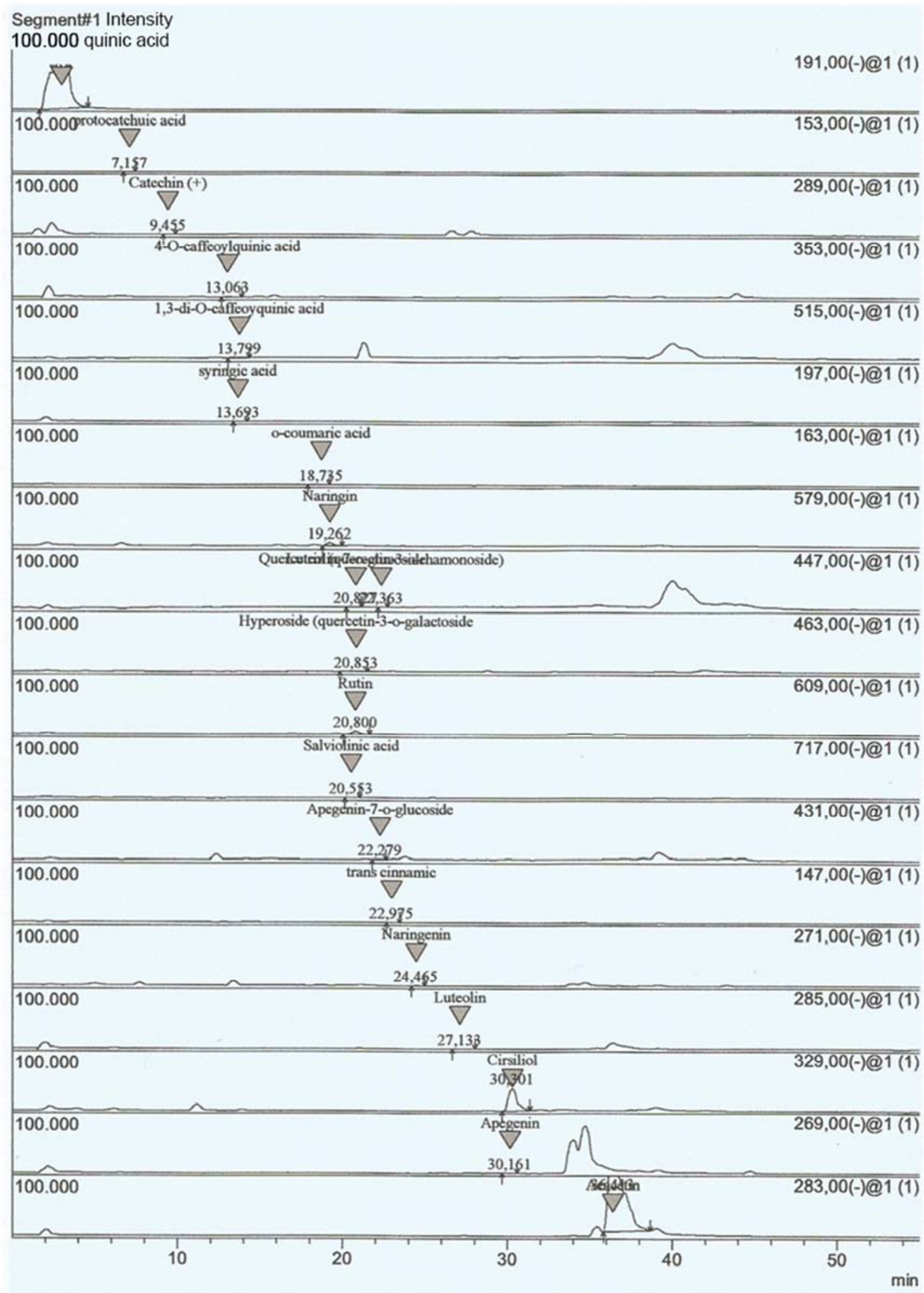

Figure 2. Total ion chromatogram of phenolic compounds from inermis Opuntia ficus-indica. 


\subsubsection{Phenolic Acids}

The methodology used allowed the identification of 9 phenolic acids, presented in Table 1. Compound (1) was eluted at $3.01 \mathrm{~min}$ and detected at $[\mathrm{M}-\mathrm{H}]-\mathrm{m} / \mathrm{z} 191$. Compared to the analytical standard, compound 1 was identified as quinic acid (Figure 3). The compound (2) recorded at [M-H]- $m / z 147$ at 22.97 min was identified as trans cinnamic acid. Based on the fragmentation pattern described by Schaldach and co-authors [12], the fragment ion observed at $\mathrm{m} / \mathrm{z} 119$ corresponded to [M-H-CO]- (Figure 4). Compound (3) showed a [M-H]- peak at $\mathrm{m} / \mathrm{z} 153$ and a retention time of $7.15 \mathrm{~min}$. Compared to the analytical standard, no daughter ions were detected and compound (3) was identified as protocatechuic acid (Figure 5). Compound (4) showed a [M-H]- peak at $\mathrm{m} / \mathrm{z} 197$ at $13.69 \mathrm{~min}$ and was identified as syringic acid (Figure 6). Ion of $\mathrm{m} / \mathrm{z} 182$ was the major product ion of the parent ion [M-H]- $m / z 197$ and corresponded to $\left[\mathrm{M}-\mathrm{H}-\mathrm{CH}_{3}\right]^{-}$. Compound (5) showed a $[\mathrm{M}-$ $\mathrm{H}$ ]- peak at $\mathrm{m} / \mathrm{z} 353.00$ and a retention time of $13.06 \mathrm{~min}$. No fragment ions were detected and compound (5) was identified as 4-O-caffeoylquinic acid (Figure 7). Compound (6) was eluted at $13.79 \mathrm{~min}$ and showed a [M-H]- peak at $\mathrm{m} / \mathrm{z}$ 515.00. Compared to the standard, it was identified as 1,3-di$O$-caffeoylquinic acid (cynarin). The fragment ion peak observed at $\mathrm{m} / \mathrm{z} 500$ corresponded to $\left[\mathrm{M}-\mathrm{H}-\mathrm{CH}_{3}\right]$ and that at $\mathrm{m} / \mathrm{z} 353$ corresponded to the chlorogenic acid (Figure 8). Compound (7) showed a [M-H]- peak at $m / z 193.00$ and a retention time of $17.31 \mathrm{~min}$ and was identified as trans ferulic acid. The fragment ion peak at $m / z 119$ corresponded to $\left[\mathrm{M}-\mathrm{H}-\mathrm{CO}_{2}-2 \mathrm{CH}_{3}\right]$ (Figure 9). Compound (8) eluted at $18.73 \mathrm{~min}$, recorded at $[\mathrm{M}-\mathrm{H}]-\mathrm{m} / \mathrm{z} 163$ and identified as $O-$ coumaric acid. Finally, Compound (9) recorded at $[\mathrm{M}-\mathrm{H}]-$ $\mathrm{m} / \mathrm{z} 717$ at $20.55 \mathrm{~min}$ was identified as salvianolic acid B (Figure 10).

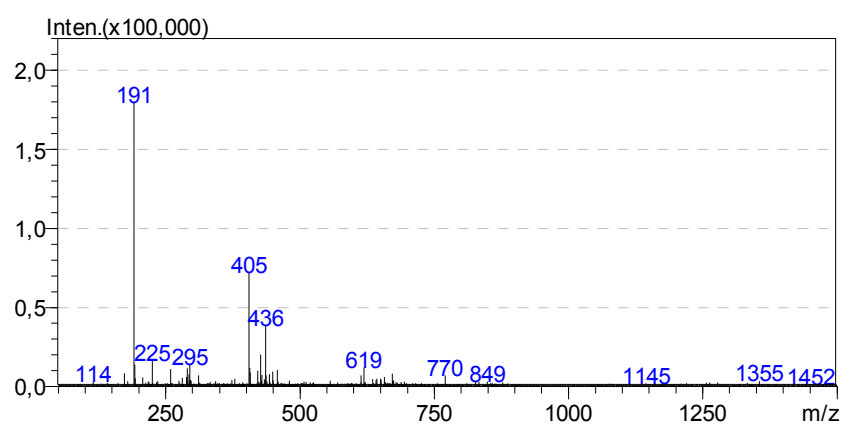

Figure 3. Mass spectrum of quinic acid.

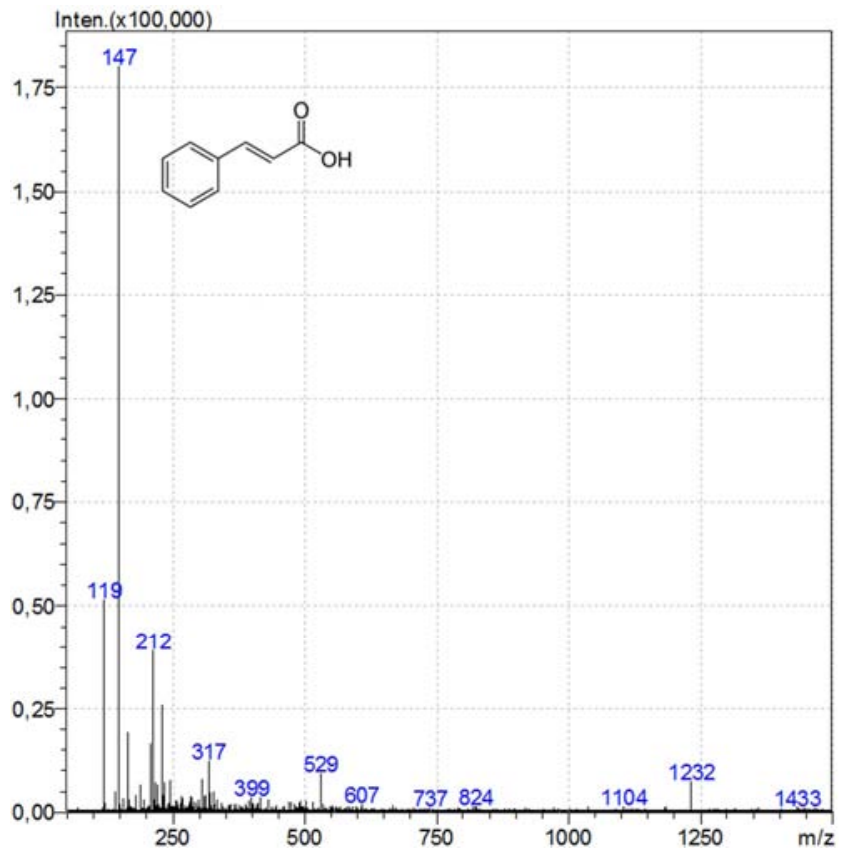

Figure 4. Mass spectrum of trans cinnamic acid.

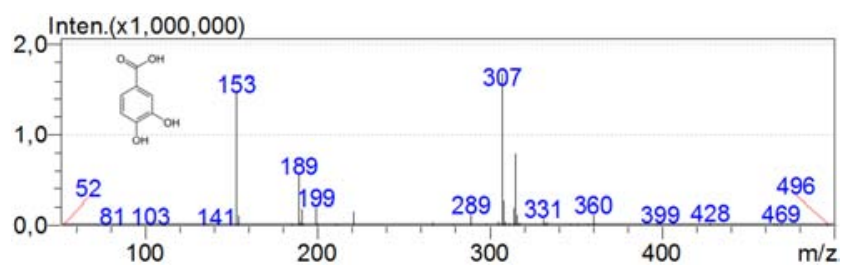

Figure 5. Mass spectrum of protocatechuic acid.

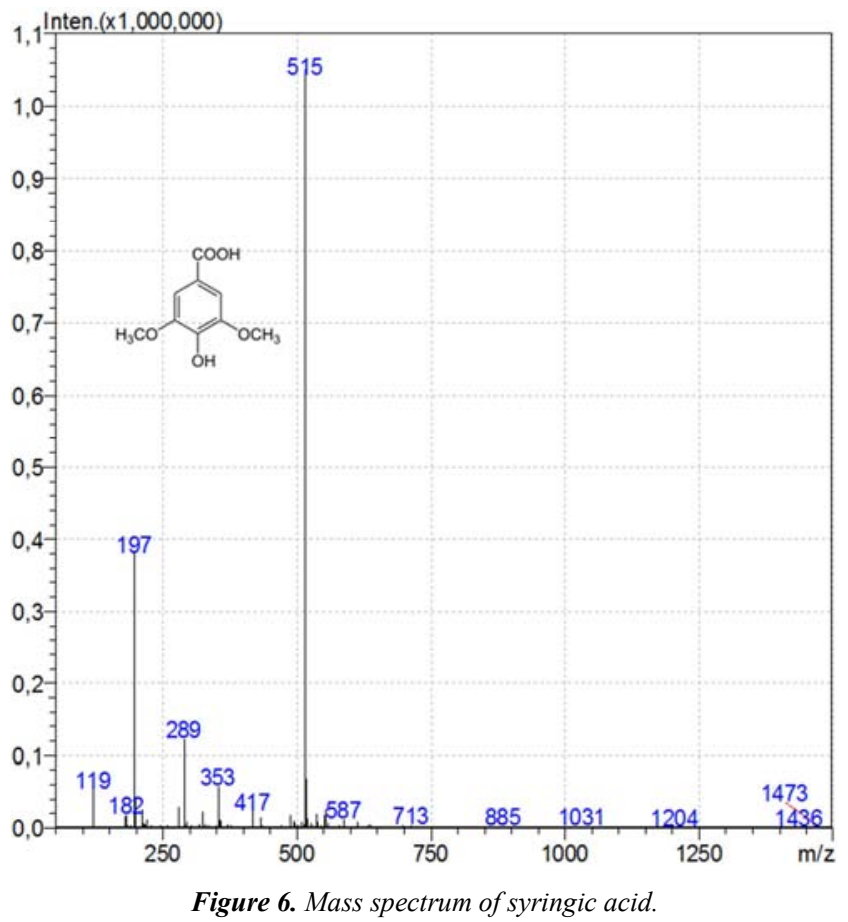




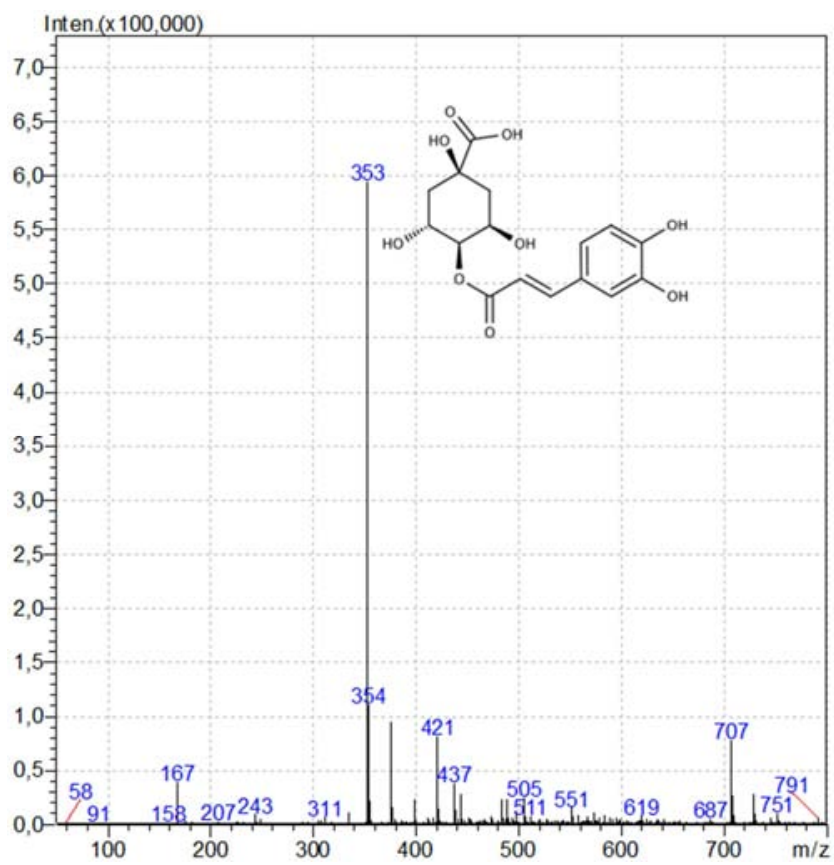

Figure 7. Mass spectrum of 4-O-caffeoylquinic acid.

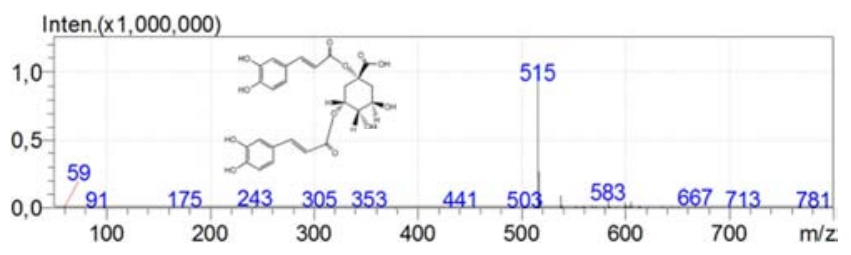

Figure 8. Mass spectrum of 1,3-di-O-caffeoylquinic acid.

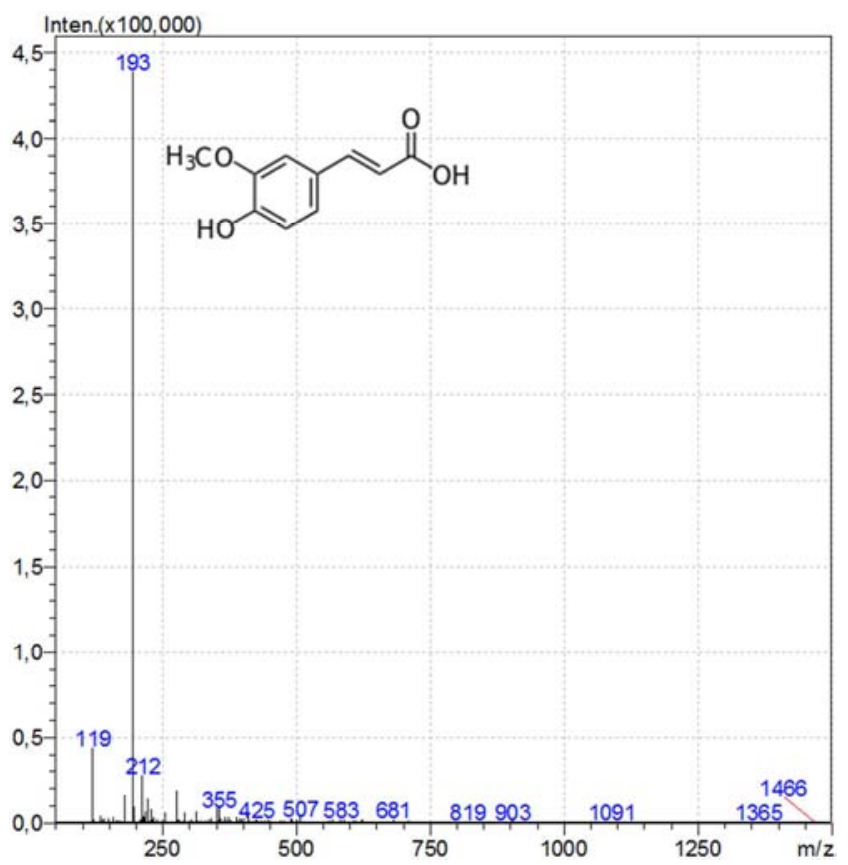

Figure 9. Mass spectrum of trans ferulic acid.

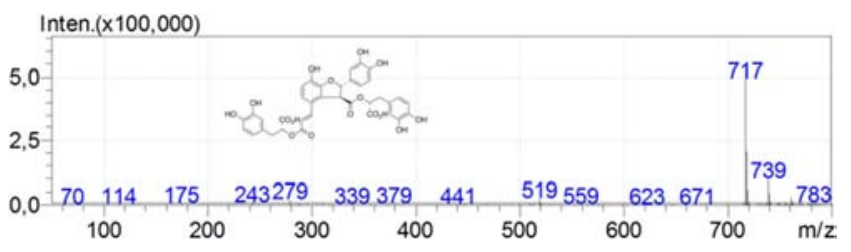

Figure 10. Mass spectrum of salvianolic acid B.

\subsubsection{Flavan-3-ol}

Compound (10) was eluted at $9.45 \mathrm{~min}$ and showed a [MH]- peak at $m / z$ 289. A fragment ion was recorded at $m / z$ 245. Based on the MS fragmentation pathway, the retention time and the analytical standard, compound (10) was identified as $(+)$ catechin (Figure 11).

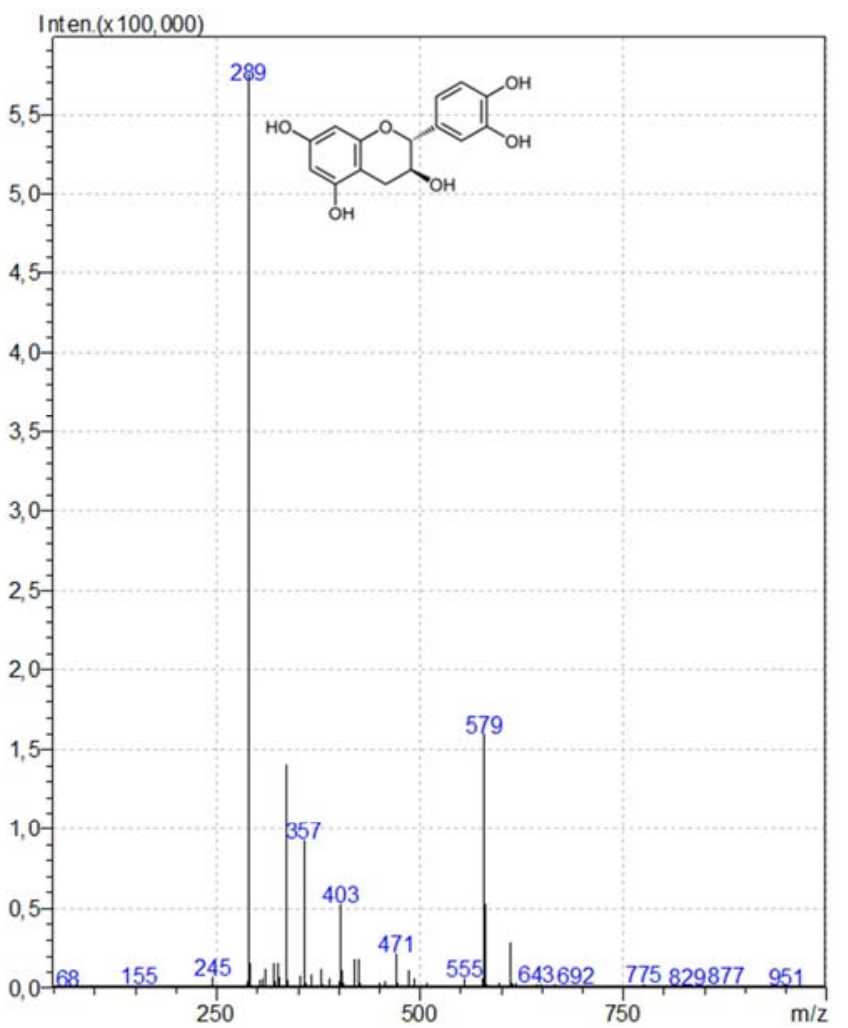

Figure 11. Mass spectrum of catechin (+).

\subsubsection{Flavanone}

Two flavanones were identified. The first one (compound (11)) showed a [M-H]- peak at $\mathrm{m} / z 579$ at $19.26 \mathrm{~min}$. Based on the analytical standard mass spectrum, compound (11) was identified as narengin (Figure 12). The fragment ion recorded at $\mathrm{m} / \mathrm{z} 118$ may be generated from the completely fragmented precursor ion at $\mathrm{m} / z 271$ which was yielded by the neutral loss of rutinose [13]. The second one (compound (12)) showed a [M-H]- peak at $\mathrm{m} / z 271$ and a retention time of $24.46 \mathrm{~min}$. A fragment ion was recorded at $\mathrm{m} / \mathrm{z} 175$ (Figure 13). Compound 12 was identified as naringenin and its daughter ion was yielded after the loss of the $\mathrm{B}$ ring $[\mathrm{M}-$ $\mathrm{H}-$ ring $\mathrm{B}]^{-}[14]$. 


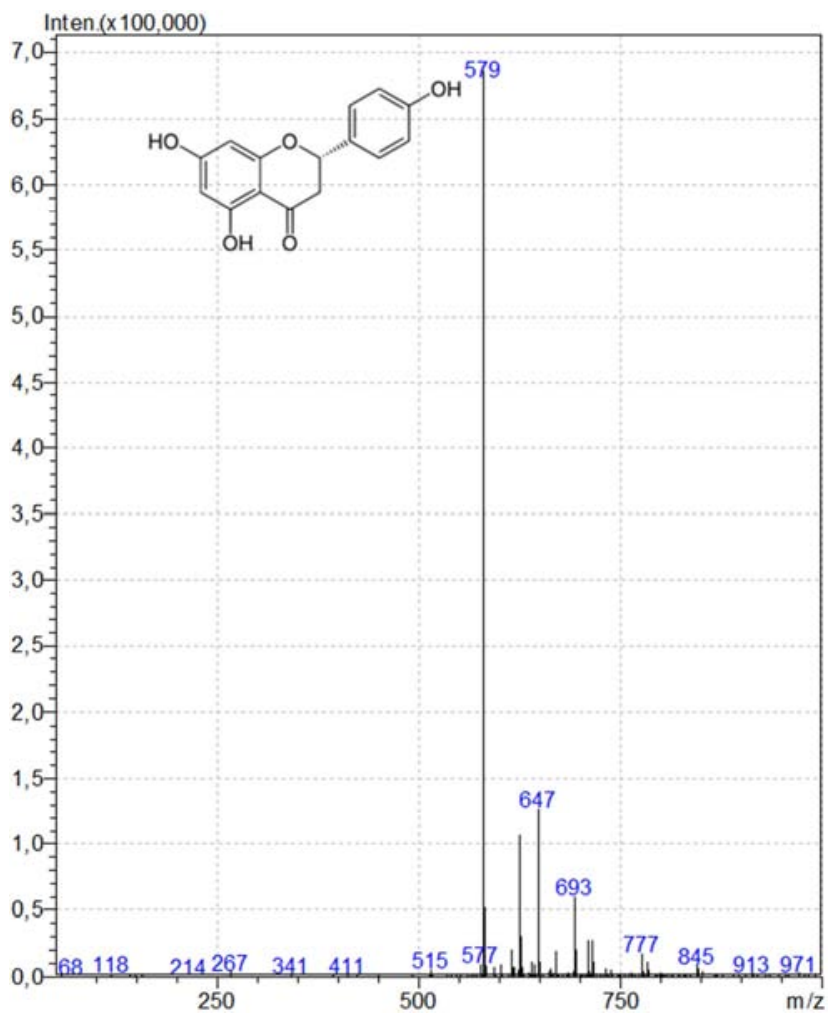

Figure 12. Mass spectrum of naringin.

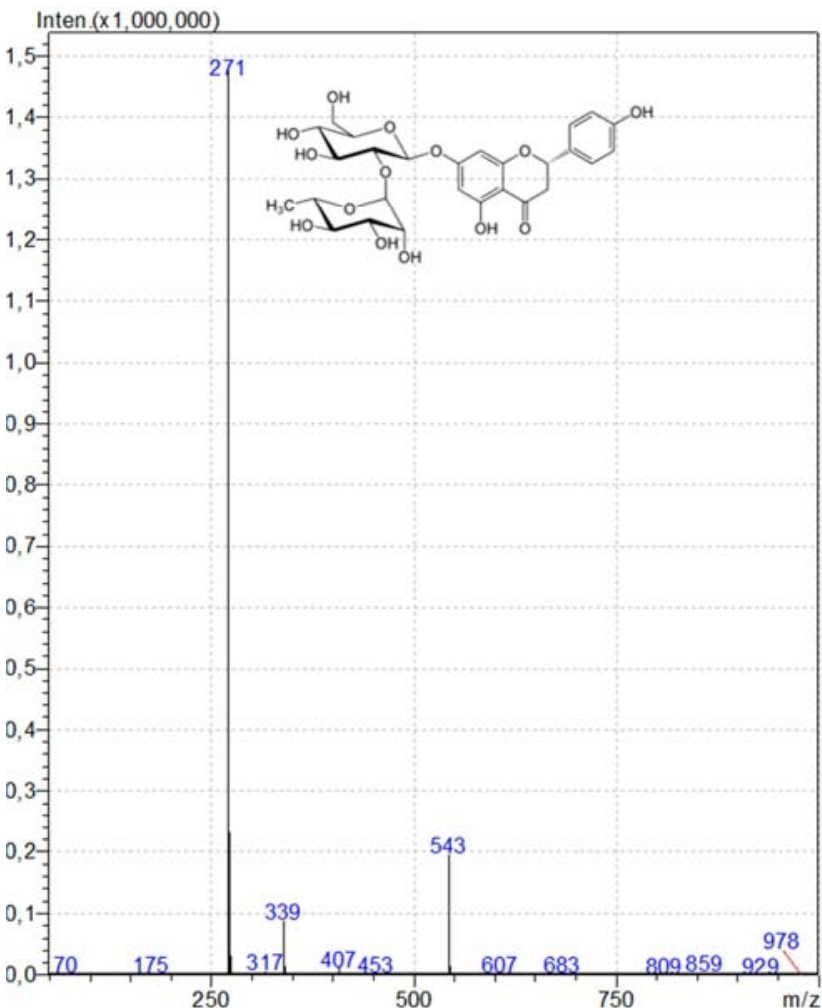

Figure 13. Mass spectrum of naringenin.

\subsubsection{Flavonols}

In this study, 3 flavonols were identified. Compound (13) showed a [M-H]- peak at $m / z 609$ at $20.80 \mathrm{~min}$, and was therefore identified as rutin (Figure 14). Compound (14) was eluted at $20.85 \mathrm{~min}$, recorded at $[\mathrm{M}-\mathrm{H}]-\mathrm{m} / \mathrm{z} 463$ and therefore identified as Quercetin-3-O-galactoside (Figure 15). Compound (15) showed a [M-H]- peak at $m / z 447$ and a retention time of $22.36 \mathrm{~min}$, and was therefore identified as quercetrin. The fragment ion at $\mathrm{m} / \mathrm{z} 301$ was formed by the loss of the rhamnose moiety from the glucoside (Figure 16).
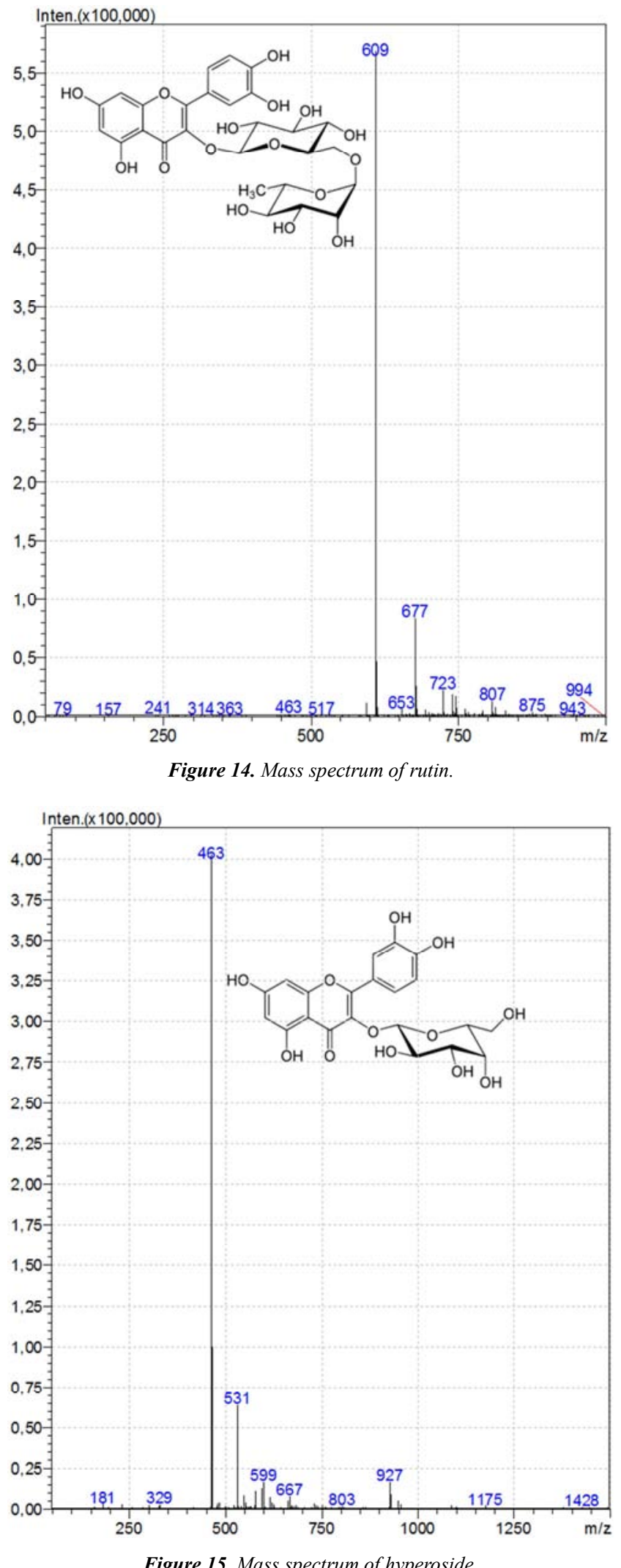


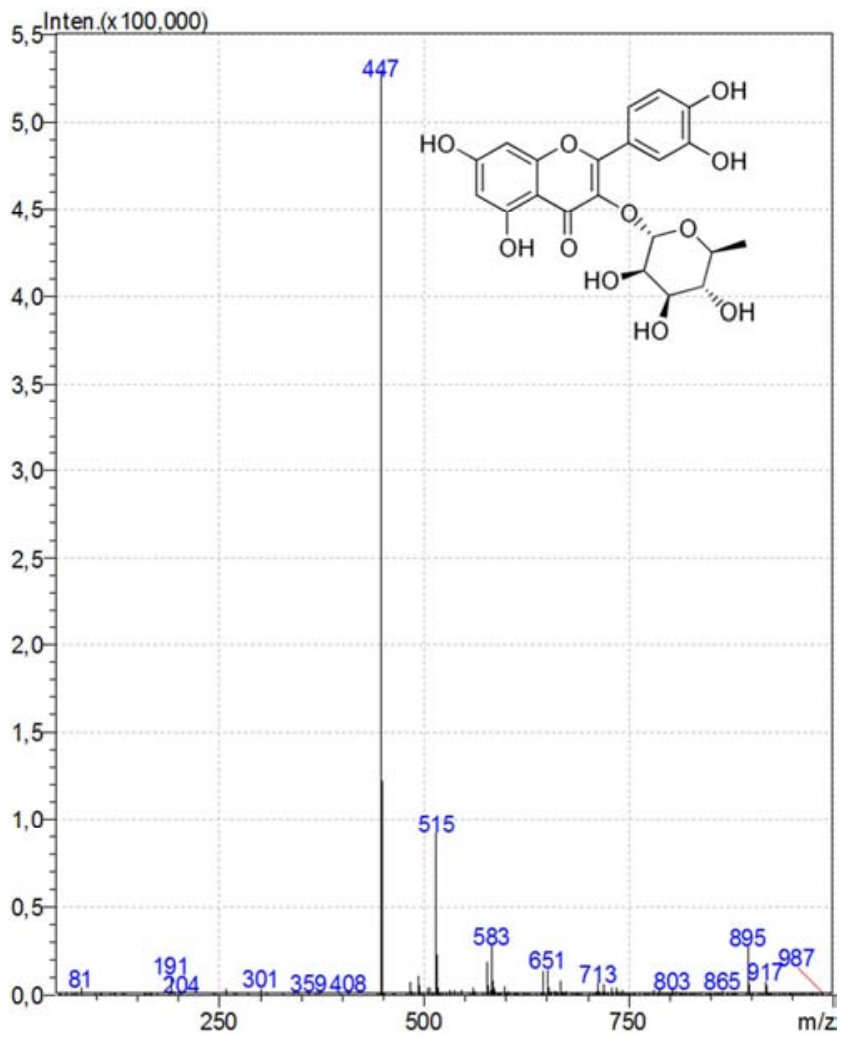

Figure 16. Mass spectrum of quercetrin.

\subsubsection{Flavones}

In addition to flavonols, 6 flavones were identified in Opuntia ficus-indica var inermis fruits. Compound (16) showed a [M-H]- peak at $\mathrm{m} / \mathrm{z} 447$ at $20.82 \mathrm{~min}$, and was therefore identified as luteolin 7-O-glucoside or Cynaroside (Figure 17). Compound (17) showed a [M-H]- peak at $m / z$ 431 and a retention time of $22.27 \mathrm{~min}$, and was therefore identified as apigenin-7-O-glucoside. A fragment ion was generated at $\mathrm{m} / \mathrm{z} 269$ after the loss of an hexose moiety from the parent ion (Figure 18). Compound (18) was eluted at $27.13 \mathrm{~min}$ and recorded at $[\mathrm{M}-\mathrm{H}]-\mathrm{m} / z 285$, and was therefore identified as luteolin (Figure 19). No fragment ions were detected according to luteolin defragmentation mass spectrum reported by Fabre and collaborators [14]. Compound (19) showed a [M-H]- peak at $m / z 269$ at 30.16 min, and was therefore identified as apigenin (Figure 20). The $[\mathrm{M}-\mathrm{H}]-$ fragmentation pathway of this flavone reported by Fabre et al. [14] was not observed. Compound (20) showed a [M-H]- peak at $\mathrm{m} / \mathrm{z} 329$ and a retention time of $30.30 \mathrm{~min}$, and was therefore identified as cirsiliol (Figure 21). Compound (21) showed a [M-H]- peak at $m / z 283$ and a retention time of $36.41 \mathrm{~min}$, and was identified as acacetin. A fragment pic was observed at $\mathrm{m} / \mathrm{z} 268$ and corresponded to $\left[\mathrm{M}-\mathrm{H}-\mathrm{CH}_{3}\right]$ - (Figure 22).
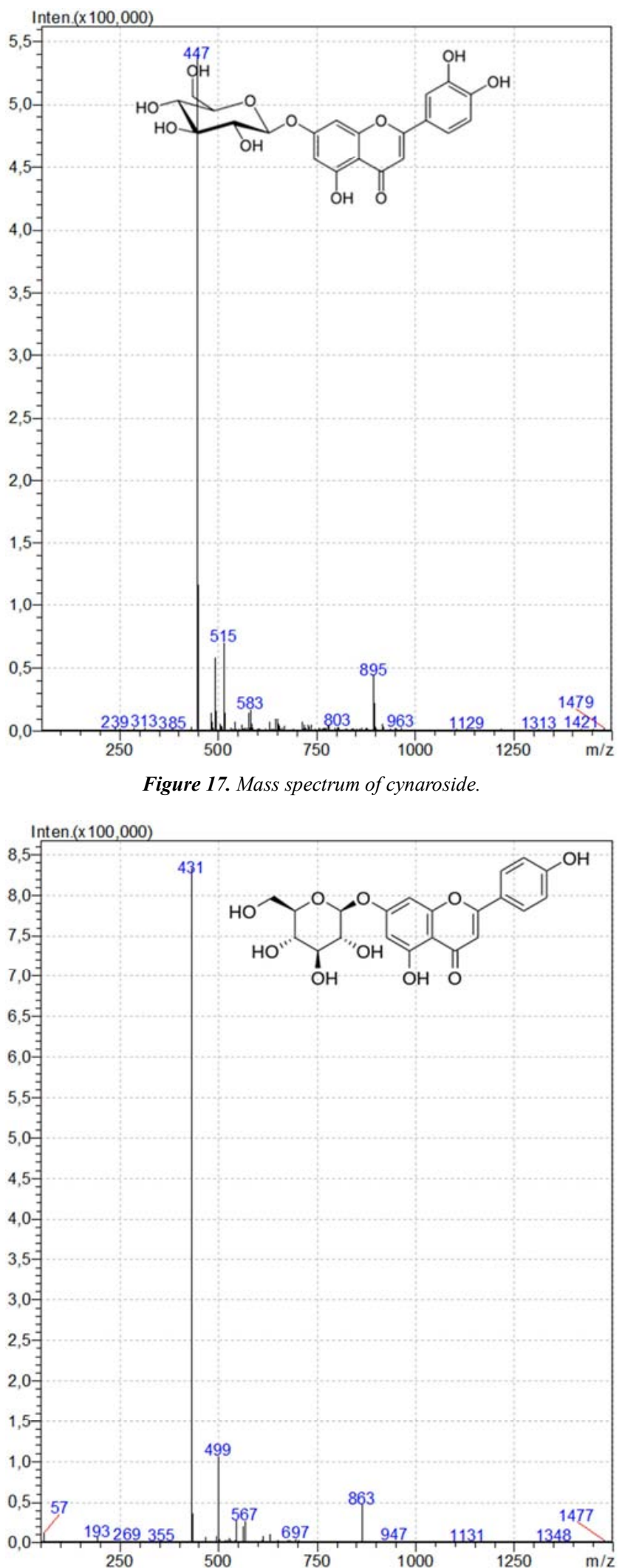

Figure 18. Mass spectrum of Apigenin-7-O-glucoside. 


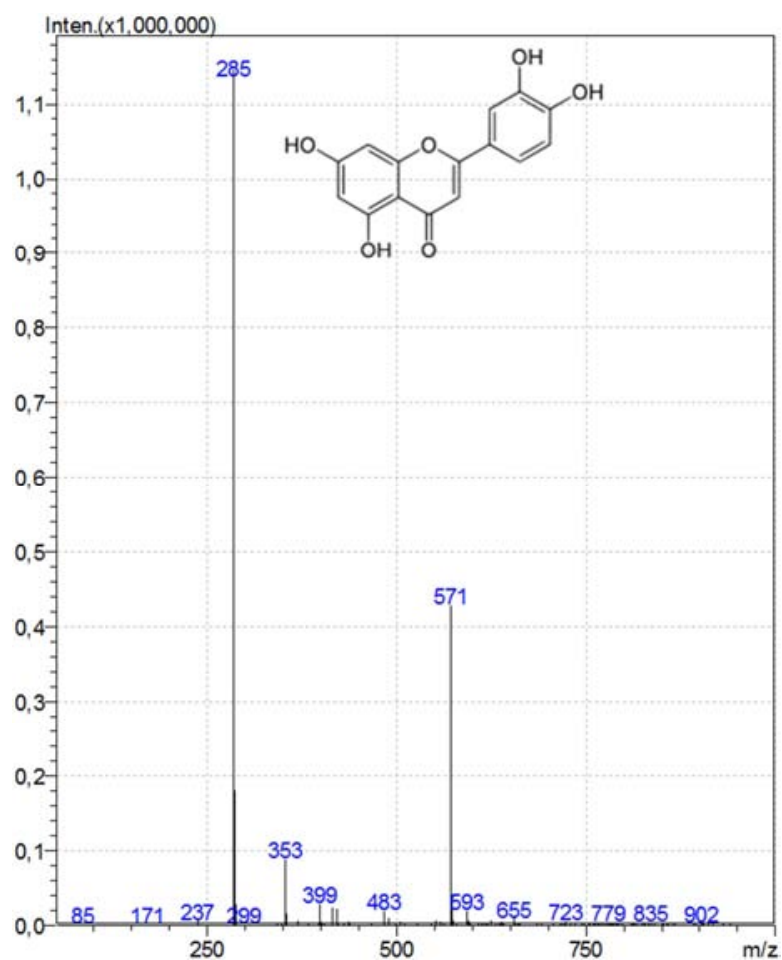

Figure 19. MS spectra of Luteolin.

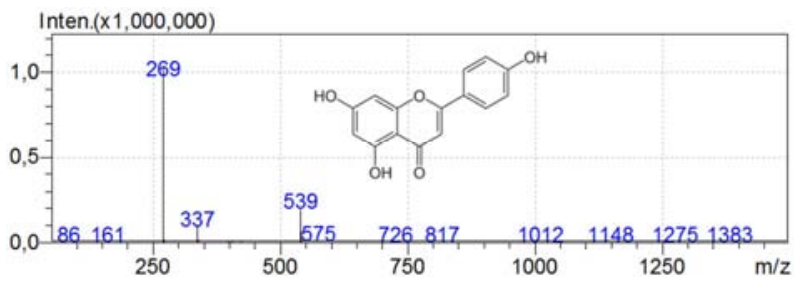

Figure 20. Mass spectrum of apigenin.

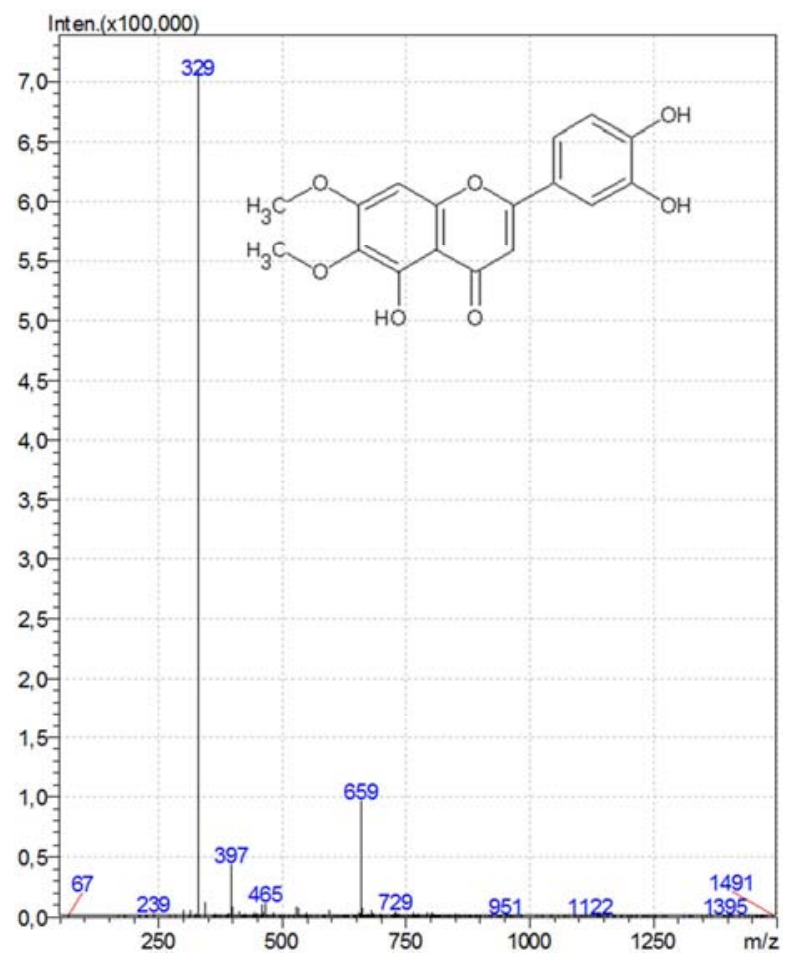

Figure 21. Mass spectrum of cirsiliol.

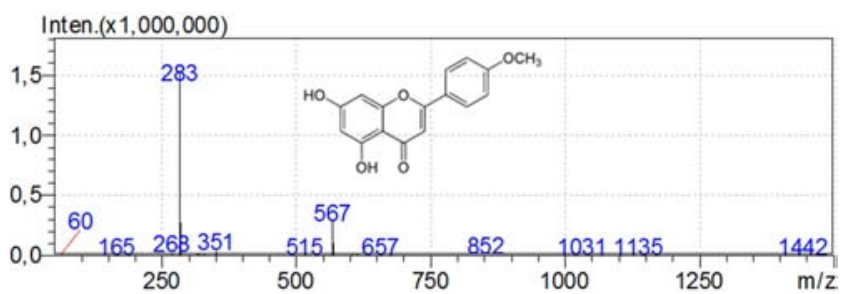

Figure 22. Mass spectrum of acacetin.

\subsubsection{Betanin and Betanidin}

The molecular ion $[\mathrm{M}+\mathrm{H}]+$ peak of betanin was identified at $m / z 551$. The corresponding retention time was $1.665 \mathrm{~min}$. The mass spectrum (Figure 20) showed a daughter ion at $\mathrm{m} / \mathrm{z}$ 389. This fragment ion was produced by fragmentation of the parent ion of $\mathrm{m} / \mathrm{z}$ of 551 assigned to betanin and indicated that it corresponds to the protonated aglycone betanidin obtained by glucose loss. Our results are in accordance with those reported by Belhadj Slimen et al. [9] and Nestora et al. [15].

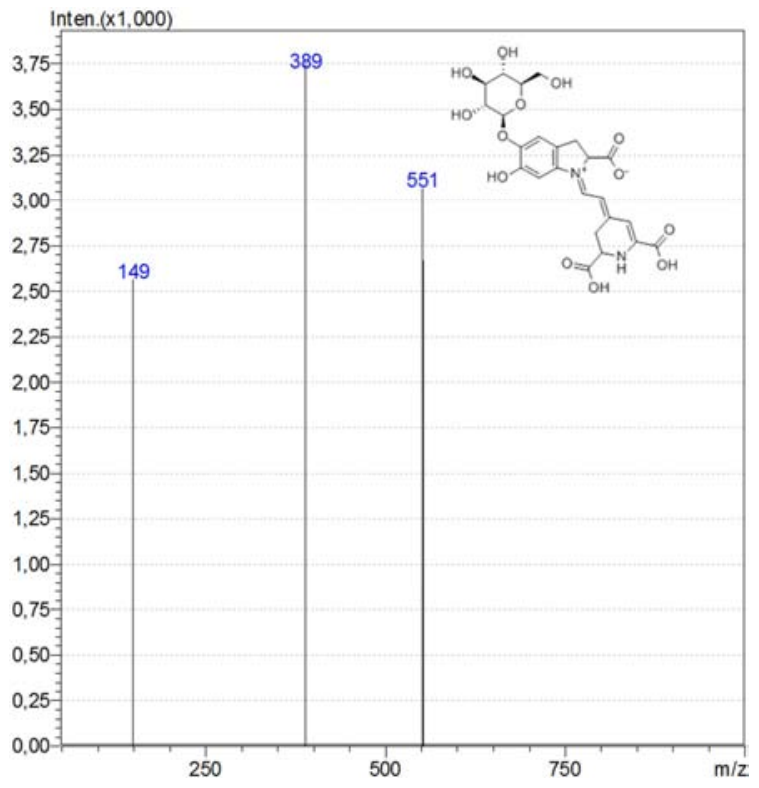

Figure 23. Mass spectrum of betanin.

\subsubsection{Undetected Peaks}

Undetectable peaks can result from several mechanisms. A compound can be present in a sample, but at low concentration below the detection limit of the spectrometer. It can also be truly absent from the sample. Alternatively, a compound may be present in the sample at a concentration above the detection limit of the mass spectrometer. The technical issues related to sample preparation or processing influence greatly the detection of its compounds. In all cases, a compound should be reported as a missing value in the resultant data set [16].

Undetected compounds are cited in Table 1. Isorhamnetin 3-O-rutinoside was detected in Tunisian spineless Opuntia ficus-indica fruits using an LCQ DECA ion trap mass spectrometer equipped with an ESI source and run by Xcalibur software [17]. Quercetin, and Kaempferol were also reported for this species $[18,19]$. 
Table 1. Characterization of phenolic compounds in the Opuntiaficus-indica fruits by LC--MS using ESI negative ion mode.

\begin{tabular}{|c|c|c|c|}
\hline Phenolic compound & Empirical formula & Retention time (min) & $m / z$ peak $[M-H]$ \\
\hline Quinic acid (1) & $\mathrm{C}_{7} \mathrm{H}_{12} \mathrm{O}_{6}$ & 3.017 & 191.00 \\
\hline trans cinnamic acid (2) & $\mathrm{C}_{9} \mathrm{H}_{8} \mathrm{O}_{2}$ & 22.975 & 147.00 \\
\hline Protocatechuic acid (3) & $\mathrm{C}_{7} \mathrm{H}_{6} \mathrm{O}_{4}$ & 7.157 & 153.00 \\
\hline Syringic acid (4) & $\mathrm{C}_{9} \mathrm{H}_{10} \mathrm{O}_{5}$ & 13.693 & 197.00 \\
\hline 4-O-caffeoylquinic acid (5) & $\mathrm{C}_{16} \mathrm{H}_{18} \mathrm{O}_{9}$ & 13.063 & 353.00 \\
\hline 1,3-di- $O$-caffeoylquinic acid (6) & $\mathrm{C}_{25} \mathrm{H}_{24} \mathrm{O}_{12}$ & 13.799 & 515.00 \\
\hline trans ferulic acid (7) & $\mathrm{C}_{10} \mathrm{H}_{10} \mathrm{O}_{4}$ & 17.317 & 193.00 \\
\hline$O$-coumaric acid (8) & $\mathrm{C}_{9} \mathrm{H}_{8} \mathrm{O}_{3}$ & 18.735 & 163.00 \\
\hline Salviolinic acid (9) & $\mathrm{C}_{36} \mathrm{H}_{30} \mathrm{O}_{16}$ & 20.553 & 717.00 \\
\hline Catechin $(+)(10)$ & $\mathrm{C}_{15} \mathrm{H}_{14} \mathrm{O}_{6}$ & 9.455 & 289.00 \\
\hline Naringin (11) & $\mathrm{C}_{27} \mathrm{H}_{32} \mathrm{O}_{14}$ & 19.262 & 579.00 \\
\hline Naringenin (12) & $\mathrm{C}_{15} \mathrm{H}_{12} \mathrm{O}_{5}$ & 24.465 & 271.00 \\
\hline Rutin (13) & $\mathrm{C}_{27} \mathrm{H}_{30} \mathrm{O}_{16}$ & 20.800 & 609.00 \\
\hline Hyperoside (quercetin-3-O-galactoside) (14) & $\mathrm{C}_{21} \mathrm{H}_{20} \mathrm{O}_{12}$ & 20.853 & 463.00 \\
\hline Quercetrin (quercetin-3-O-rhamnoside) (15) & $\mathrm{C}_{21} \mathrm{H}_{20} \mathrm{O}_{11}$ & 22.363 & 447.00 \\
\hline Luteolin-7-O-glucoside (16) & $\mathrm{C}_{21} \mathrm{H}_{20} \mathrm{O}_{11}$ & 20.827 & 447.00 \\
\hline Apegenin-7-O-glucoside (17) & $\mathrm{C}_{21} \mathrm{H}_{20} \mathrm{O}_{10}$ & 22.279 & 431.00 \\
\hline Luteolin (18) & $\mathrm{C}_{15} \mathrm{H}_{10} \mathrm{O}_{6}$ & 27.133 & 285.00 \\
\hline Apigenin (19) & $\mathrm{C}_{15} \mathrm{H}_{10} \mathrm{O}_{5}$ & 30.161 & 269.00 \\
\hline Cirsiliol (20) & $\mathrm{C}_{17} \mathrm{H}_{14} \mathrm{O}_{7}$ & 30.301 & 329.00 \\
\hline Acacetin (21) & $\mathrm{C}_{16} \mathrm{H}_{12} \mathrm{O}_{5}$ & 36.413 & 283.00 \\
\hline Gallic acid & $\mathrm{C}_{7} \mathrm{H}_{6} \mathrm{O}_{5}$ & - & ND \\
\hline Epicatechin & $\mathrm{C}_{15} \mathrm{H}_{14} \mathrm{O}_{6}$ & - & ND \\
\hline Chlorogenic acid & $\mathrm{C}_{16} \mathrm{H}_{18} \mathrm{O}_{9}$ & - & ND \\
\hline 3,4-di- $O$-caffeoylquinic acid & $\mathrm{C}_{25} \mathrm{H}_{24} \mathrm{O}_{12}$ & - & ND \\
\hline 4,5-di- $O$-caffeoylquinic acid & $\mathrm{C}_{25} \mathrm{H}_{24} \mathrm{O}_{12}$ & - & ND \\
\hline Caffeic acid & $\mathrm{C}_{9} \mathrm{H}_{8} \mathrm{O}_{4}$ & - & ND \\
\hline p-coumaric acid & $\mathrm{C}_{9} \mathrm{H}_{8} \mathrm{O}_{3}$ & - & ND \\
\hline Rosmarinic acid & $\mathrm{C}_{18} \mathrm{H}_{16} \mathrm{O}_{8}$ & - & ND \\
\hline Myricetin & $\mathrm{C}_{15} \mathrm{H}_{10} \mathrm{O}_{8}$ & - & ND \\
\hline Silymarin & $\mathrm{C}_{25} \mathrm{H}_{22} \mathrm{O}_{10}$ & - & ND \\
\hline Quercetin & $\mathrm{C}_{15} \mathrm{H}_{10} \mathrm{O}_{7}$ & - & ND \\
\hline Kaempferol & $\mathrm{C}_{15} \mathrm{H}_{10} \mathrm{O}_{6}$ & - & ND \\
\hline Cirsilineol & $\mathrm{C}_{18} \mathrm{H}_{16} \mathrm{O}_{7}$ & - & ND \\
\hline Isorhamnetin & $\mathrm{C}_{16} \mathrm{H}_{12} \mathrm{O}_{7}$ & - & ND \\
\hline Aucubin & $\mathrm{C}_{15} \mathrm{H}_{22} \mathrm{O}_{9}$ & - & ND \\
\hline
\end{tabular}

\subsection{Quantification and Biological Importance}

Quantification of phenolic acids, flavonoids and betaninin from Opuntia ficus-indica fruits was ensured using calibration curves of analytical standards. Total betanin content was evaluated at $1,616 \mathrm{~g} / \mathrm{Kg}$. Our result is too much higher than the findings of Tesoriere and co-authors [5] $(12.1 \mathrm{mg} / \mathrm{Kg})$ as well as those of Buteraand co-workers [20] $(10.4 \mathrm{mg} / \mathrm{Kg})$. The observed difference may be due to the ripeness state of the collected samples, their provenance and the harvest season [21-23].

Total phenolics accounted at $481.139 \mathrm{mg} / \mathrm{Kg}$. Respective content of each identified molecule is reported in Table 2. Quinic acid is the major phenolic present in spineless Opuntia ficus-indica fruits. It is a cyclic polyol and an important intermediate product in the biosynthesis of aromatic compounds (flavonoids and phenol carboxylic acids) in higher plants, humans and animals [24]. Cirsiliol, acacetin, trans cinnamic acid, rutin and naringin were present at lower concentrations (respectively 8.797, 7.191, 4.288, 3.180 and $1.059 \mathrm{mg} / \mathrm{Kg}$ ). Cirsiliol has previously been isolated from other Salvia species [25]. It is a competitive low affinity benzodiazepine receptor ligand [26] known for its sedative and hypnotic effects [27]. It is the most potent inhibitor of arachidonate 5-lipoxygenase, an enzyme responsible for leukotriene biosynthesis [28]. Acacetin is a 5,7-dihydroxy-4'methoxyflavone that is broadly distributed in plants, and responsible for many color shades [29]. Acacetin has been reported for its antiperoxidative, antiinflammatory, antiplasmodial and antiproliferative effects [30-33]. In addition, acacetin was reported to inhibit glutathione reductase and cytochrome P450 [34, 35]. Cinnamic acid is an organic acid occurring naturally in plants that has low toxicity and a broad spectrum of antioxidant and biological activities [36]. The antioxidant capacity relative to trolox indicated that the cinnamic acid derivatives are more efficient than their benzoic counterparts [37]. Rutin, also called rutoside, quercetin-3-Orutinoside and sophorin, is the glycoside combining the flavonol quercetin and the disaccharide rutinose. Rutin is a highly potent molecule due to its strong antioxidant properties. It was used not only as antimicrobial, antifungal, and antiallergic agent; but also for the treatment of various chronic diseases such as cancer, diabetes, hypertension and hypercholesterolemia. Compared to other flavonoids, rutin is considered as a nontoxic and nonoxidizable molecule [38]. Both naringin and naringenin are strong antioxidants $[39,40]$. However, the former is less potent compared with the latter 
because the sugar moiety in naringin causes steric hindrance of the scavenging group. Naringin was reported for its favorable effects on obesity, hyperlipidemia, hypertension, cardiac function, hyperglycemia and diabetes, hepatic function, inflammation, oxidative stress and free radical damage [41]. Quercetin, a flavonol with proven health promoting properties, is one of the most potent antioxidants among polyphenols [42, 43]. Two quercetin derivates (quercetin $O$-glycosides) were identified in Opuntia fruits: hyperoside and quercetrin at respective concentrations 0.234 and $0.033 \mathrm{mg} / \mathrm{Kg}$. Quercetin derivatives can be both lipo- and hydrophilic, depending on the type of substituents in the molecule. Glycosylation of at least one hydroxyl group of quercetin derivatives results in an increase of its hydrophilicity [44]. In addition to quercetin derivates, we quantified other antioxidant molecules such as protocatechuic acid (or 3,4-Dihydroxybenzoic acid) which is a type of phenolic acid and a major metabolite of antioxidant polyphenols, as well as 4-O-caffeoylquinic acid, also known as cryptochlorogenic acid, which is a cinnamic acid derivate and possesses antioxidant properties.

Table 2. Relative concentration of identified phenolic compounds in Opuntia ficus-indica fruits.

\begin{tabular}{ll}
\hline Molecule & Relative concentration $\mathbf{( m g / K g )}$ \\
\hline Quinic acid & 454.716 \\
Protocatchuic acid & 0.127 \\
Catechin $(+)$ & 0.074 \\
4-O-caffeoylquinic acid & 0.127 \\
Syringic acid & 0.852 \\
1,3-di-O-caffeoylquinic acid & 0.124 \\
trans ferulic acid & 0.006 \\
$O$-coumaric acid & 0.406 \\
Naringin & 1.059 \\
Salviolinic acid & 0.057 \\
Rutin & 3.180 \\
Luteolin-7-O-glucoside & 0.057 \\
Hyperoside & 0.234 \\
Apegenin-7-O-glucoside & 0.018 \\
Quercetrin & 0.033 \\
trans cinnamic acid & 4.288 \\
Naringenin & 0.003 \\
Luteolin & 0.014 \\
Apigenin & 0.002 \\
Cirsiliol & 8.797 \\
Acacetin & 7.191 \\
\hline
\end{tabular}

Finally, it is important to note that methanolic fruit extract of Opuntia ficus-indica was reported for its important anticancer activity. This extract was shown to induce apoptosis as evident by loss of cell viability, enhanced ROS, alteration in mitochondrial membrane potential due to changes in lipid peroxidation, and increased DNA damage in cancer cells [45]. Hence, it can be concluded that Opuntia fruits anticancer activity is due to their ability to modulate mitochondrial functions, which are important key players in stem cell fate [46, 47], and which alteration is strongly associated to carcinogenesis [48, 49].

\subsection{Antioxidant Activity}

The antioxidant activity of spineless Opuntia ficus-indica fruits was assessed using the DPPH free radical scavenging test, and was evaluated at $0.262 \mathrm{mg}$ Trolox Equivalent $/ \mathrm{g}$. This antioxidant activity seems to be related to the extraction solvent, which allowed extracting high amounts of betanin and phenolic acids, but few concentrations of flavonoids. Our findings are in accordance with Jorge and co-authors [50] who optimized the extraction of phenolic compounds from Opuntia ficus-indica skin in a reflux system using $45 \%$ ethanol.

\section{Conclusion}

In fruits from spineless $O$. ficus-indica growing in Sawaf, Tunisia, it was possible to detect 38 compounds from which 23 were identified. These compounds included different classes of phenolics, namely phenolic acids and different families of flavonoids (flavan-3-ol, flavanones, flavonols, flavones) as well as betanin and its aglycone betanidin. Besides the quantification of phenolics and betanin from Opuntia ficus-indica fruits, the paper devoted a special effort to describe some antioxidant and biological activities of the identified compounds. Our results show that Opuntia fruits can offer a high interesting value for food and pharmaceutical industries for which the development of a real cactus-sourcing branch is awaited.

\section{Acknowledgment}

The authors thank Pr. Touhami Khorchani, the head of the Central Laboratory of the Institute of Arid Regions (Medenine, Tunisia), for accepting, funding and facilitating our samples analysis in his laboratory.

\section{References}

[1] Small E, Catling PM. Blossoming treasures of biodiversity 11. Cactus pear (Opuntia ficus-indica)- miracle of water conservation. Biodiversity 2004; 5: 27-31.

[2] Piga A. Cactus pear: A fruit of nutraceutical and functional importance. Journal of the Professional Association for CactusDevelopment 2004; 9-22.

[3] Bekir EA. Cactus pear (Opuntia ficus-indica) in turkey: growing regions and pomological traits of cactus pear fruits. Acta Horticulture 2006; 728: 51-54.

[4] Choi J, Lee CK, Lee YC, Moon YI, Park H, Han YN. Biological activities of the extracts from fruit and stemof prickly pear (Opuntia ficus-indica var. saboten)-II. Effects ondietary induced hyperlipidemia. Korean Journal of Pharmacology 2002; 33: 230-237.

[5] Tesoriere T, Butera D, Pintaudi AM, Allegra M, Livrea MA. Supplementation with cactus pear fruit decreases antioxidative stress in healthy humans: a comparative study with vitamin C. American Journal of Clinical Nutrition 2004; 80: 391-395.

[6] Nalin S, Jeon Y. Antioxidative effect of cactus pear (Opuntia ficus-indica) fruit extract on lipid peroxidation inhibition in oils and emulsion model systems. European Food Research and Technology 2004; 219: 369-376. 
[7] Siriwrdhana N, Shahidi F, Joen Y. Potential antioxidative effects of cactus pear fruit extract on radical scavenging and DNA damage reduction in human peripheral lymphocytes. Journal of food lipids 2006; 13: 445-458.

[8] Belhadj Slimen I, Najar T, Abderrabba M. Opuntia ficusindica as a Source of Bioactive and Nutritional Phytochemicals. Journal of Food and Nutrition Sciences 2016; 4: $162-169$.

[9] Belhadj Slimen I, Najar T, Abderrabba M. Chemical and antioxidant properties of betalains. Journal of Agricultural and Food Chemistry; DOI: 10.1021/acs.jafc.6b04208.

[10] Brand-Williams W., Cuvelier M. E., Berset C. 1995. Use of a free radical method to evaluate antioxidant activity. Food Science and Technology, 28: 25-30.

[11] Thaipong K., Boonprakob U., Crosby, K., Cisneros-Zevallos L., Byrne D. H., 2006. Comparison of ABTS, DPPH, FRAP, and ORAC assays for estimating antioxidant activity from guava fruit extracts. Journal of Food Composition Analysis, 19: 669-675.

[12] Schaldach B, Griitzmacher H.-Fr. The fragmentations of substituted cinnamic acids after electron impact. Organic Mass Spectrometry 1980; 15: 175-181.

[13] Xu F, Liu Y, Zhang Z, Yang C, Tian Y. Quasi-MS ${ }^{\mathrm{n}}$ identification of flavanone 7-glycoside isomers in Da Chengqi Tang by high performance liquid chromatography-tandem mass spectrometry. Chinese Medecine. 2009; 4: 1-10.

[14] Fabre N, Rustan I, de Hoffmann E, Quetin-Leclercq J. Determination of flavone, flavonol, and flavanone aglycones by negative ion liquid chromatography electrospray ion trap mass spectrometry. Journal of the American Society for Mass Spectrometry 2001; 12: 707-715.

[15] Nestora S, Merlier F, Prost E, Haupt K, Rossi C, Sum Bui BT. Solid-phase extraction of betanin and isobetanin from beetroot extracts using a dipicolinic acid molecularly imprinted polymer. Journal of Chromatography A 2016; DOI: 10.1016/j.chroma.2016.08.069.

[16] Taylor SL, Leiserowitz GS, Kim K. Accounting for undetected compounds in statistical analyses of mass spectrometry 'Omic studies. Statistical Applications in Genetics and Molecular Biology 2013; 12: 703-722.

[17] Yeddes N, Chérif JK, Guyot S, SotinH, Ayadi MT. Comparative Study of Antioxidant Power, Polyphenols, Flavonoids and Betacyanins of the Peel and Pulp of Three Tunisian Opuntia Forms. Antioxidants 2013; 2: 37-51.

[18] Mata A, Ferreira JP, Semedo C, Serra T, Duarte CMM, Bronze MR. Contribution to the characterization of Opuntia spp. Juices by LC-DAD-ESI-MS/MS. Food Chemistry 2016; 210: $558-565$

[19] Bensadon S, Hervert-Hernandez D, Sayago-Ayerdi SG, Goni I. By-products of Opuntia ficus-indica as a source of antioxidant dietary fiber. Plant Foods for Human Nutrition 2010, 65: 210-216.

[20] Butera D, Tesoriere L, DiGaudio F, BongiornoA, Allegra M, PintaudiAM, Kohen R, Liverea MA. Antioxidant Activities of Sicilian Prickly Pear (Opuntia ficus-indica) Fruit Extracts and Reducing Properties of Its Betalains: Betanin and Indicaxanthin. Journal of Agricultural and Food Chemistry 2002; 50: 6895-6901.
[21] Kumar SS, Manoj P, Shetty NP, Prakash M, Giridhar P. Characterization of major betalain pigments -gomphrenin, betanin and isobetanin from Basellarubra L. fruit and evaluation of efficacy as a natural colourant in product (ice cream) development. Journal of Food Science and Technology 2015; 52: 4994-5002.

[22] Coria Cayupán YS, Ochoa MJ, Nazareno MA. Healthpromoting substances and antioxidant properties of Opuntia $s p$. fruits. Changes in bioactive-compound contents during ripening process. Food Chemistry 2011; 126: 514-519.

[23] Ou B, Huang D, Hampsch-Woodill M, Flanagan JA, Deemer EK. Analysis of Antioxidant Activities of Common Vegetables Employing Oxygen Radical Absorbance Capacity (ORAC) and Ferric Reducing Antioxidant Power (FRAP) Assays: A Comparative Study. Journal of Agricultural and Food Chemistry 2002; 50: 3122-3128.

[24] Adamson RH, Bridges JW, Evanst ME, Williams RT. Species Differences in the Aromatization of Quinic Acid in vivo and the Role of Gut Bacteria. Biochemistry Journal 1970; 116: 437-433.

[25] Lu Y, Foo LY. Polyphenolics of Salvia--a review. Phytochemistry 2002; 59: 117-40.

[26] Marder M, Viola H, Wasowski C, Wolfman C, Waterman PG, Medina JH, Paladini AC. Cirsiliol and caffeic acid ethyl ester, isolated from Salvia guaranitica, are competitive ligands for the central benzodiazepine receptors. Phytomedicine 1996; 3: 29-31.

[27] Viola H, Wasowski C, Marder M, Wolfman C, Paladini AC, Medinn JH. Sedative and hypnotic properties of Salvia guaranitica St. Hll. and of its active principle, Cirsiliol. Phytomedicine 1997; 4: 47-51.

[28] Schneider I, Bucar F. Lipoxygenase inhibitors from natural plant sources. Part 2: medicinal plants with inhibitory activity on arachidonate 12-lipoxygenase, 15-lipoxygenase and leukotriene receptor antagonists. Phytotherapy Research 2005; 19: $263-72$.

[29] Cody V. Crystal and molecular structures of flavonoids. Progress in clinical and biological research 1988; 280: 29-44.

[30] Liao YH, Houghton PJ, Hoult JR. Novel and known constituents from Buddleja species and their activity against leukocyte eicosanoid generation. Journal of Natural Products 1999; 62: 1241-1245.

[31] Kraft C, Jenett-Siems K, Siems K, Jakupovic J, Mavi S, Bienzle U, Eich E. In vitro antiplasmodial evaluation of medicinal plants from Zimbabwe. Phytotherapy Research 2003; 17: 123-128.

[32] Singh RP, Agrawal P, Yim D, Agarwal C, Agarwal R. Acacetin inhibits cell growth and cell cycle progression, and induces apoptosis in humanprostate cancer cells: structureactivity relationship with linarin and linarin acetate. Carcinogenesis 2005; 26: 845-854.

[33] Pan MH, Lai CS, Wang YJ, Ho CT. Acacetin suppressed LPSinduced up-expression of iNOS and COX-2 in murine macrophages and TPA induced tumor promotion in mice. Biochemical Pharmacology 2006; 72: 1293-1303.

[34] Zhang K, Yang EB, Tang WY, Wang KP, Mack P. Inhibition of glutathione reductase by plant polyphenols. Biochemical Pharmacology 1997; 54: 1047-1053. 
[35] Doostdar H, Burke MD, Mayer RT. Bioflavonoids: selective substrates and inhibitors for cytochrome P450 CYP1A and CYP1B1. Toxicology 2000; 144: 31-38.

[36] Sova M. Antioxidant and antimicrobial activities of cinnamic acid derivatives. Mini-Reviews in Medicinal Chemistry 2012; 12: 749-767.

[37] Natella F, Nardini M, Di Felice M, Scaccini C. Benzoic and Cinnamic Acid Derivatives as Antioxidants: StructureActivity Relation. Journal of Agricultural and Food Chemistry 1999; 47: 1453-1459.

[38] Sharma S, Ali A, Ali J, Sahni JK, Baboota S. Rutin: therapeutic potential and recent advances in drug delivery. Expert Opinion on Investigational Drugs 2013; 22: 10631079.

[39] Renugadevi J, Prabu SM. Naringenin protects against cadmium-induced oxidative renal dysfunction in rats. Toxicology 2009; 256: 128-34.

[40] Jung UJ, Kim HJ, Lee JS, Lee MK, Kim HO, Park EJ, Kim HK, Jeong TS, Choi MS. Naringin supplementation lowers plasma lipids and enhances erythrocyte antioxidant enzyme activities in hypercholesterolemic subjects. Clinical Nutrition 2003; 22: 561-568.

[41] Alam MA, Subhan N, Rahman MM, Uddin SJ, Reza HM, Sarker SD. Effect of citrus flavonoids, naringin and naringenin, on metabolic syndrome and their mechanisms of action. Advances in Nutrition 2014; 5: 404-417.

[42] Kaur Ch, Kapoor HC. Antioxidants in fruits and vegetables the millennium's health. International Journal of Food Science and Technology 2001; 36: 703-725.

[43] Rice-Evans CA, Miller J, Paganga G. Antioxidant properties of phenolic compounds. Trends in Plant Science 1997; 2: $152-159$.

[44] Materska M. Quercetin and its derivates: chemical structure and bioactivity - A review. Polish Journal of Food and Nutrition Sciences 2008; 58: 407-413.

[45] Gnanakalai K., Gopal R. Anticancer activity of methanol fruit extract of Opuntia ficus-indica against cervical cancer using Hela cell line. International Journal of Pharma and Bio Sciences 2016; 7: B712-720.

[46] Sadaf N., Ahsan J., Ahmad S., Haque R. Mitochondria: A key player in stem cell fate. Cell Biology 2015; 1-2: 31-37.

[47] Tiwari M., Kumar Sharma L., Saxena A. K., Godbole M. M. Interaction between mitochondria and caspases: apoptotic and non-apoptotic roles. Cell Biology 2015; 1-2: 22-30.

[48] Shrivastava A. The mechanisms of mitochondria-mediated apoptosis in cancer chemotherapy. Cell Biology 2015; 1-2: $17-21$.

[49] Sharma L. K., Tiwari M., Mishra S. K. Mitochondrial alteration: a major player in carcinogenesis. Cell Biology 2015; 1-2: 8-16.

[50] Jorge A. J., Heliodoro De La G. T., Alejandro Z. C., Ruth B. C., Noé, A. C., 2013. The optimization of phenolic compounds extraction from cactus pear (Opuntia ficus-indica) skin in a reflux system using response surface methodology. Asian Pacific Journal of Tropical Biomedicine, 3: 436-442. 